\title{
COMPARISON ON THE EFFECT OF TRYUSHANADI GUGGULU AND AMRUTHADI GUGGULU IN DYSLIPIDEMIA
}

KEY WORDS: Dyslipidemia, Tryushanadi guggulu, Amruthadi guggulu, Agnimandya

\section{Dr Archana G*}

\section{Late Dr V N}

\section{Radhakrishnan}

\section{Dr Bindu PR}

Former Assistant Professor, Indian Institute of Ayurvedic Medicine and Research , Bengaluru. *Corresponding Author

Retired Professor and HOD, Dept Of Kayachikitsa, Govt Ayurveda College Thiruvananthapuram.

\section{Assistant Professor, Dept Of Kayachikitsa Govt Ayurveda College,} Thiruvananthapuram

Dyslipidemia is characterised by disorders in lipid metabolism and it is an independent and modifiable risk factor for Coronary Artery Diseases. Dyslipidemia leads to changes in serum lipoprotein levels. Dyslipidemia can be considered as a condition where Kapha, Agni,Rasa and Medas are Pathologically modified due to Agnimandya and Ahara-Viharas. The Study drug, Tryushanadi guggulu and the comparison drug Amruthadi guggulu possess Kaphamedohara, deepana, pachana, ruksha and lekhana properties. The study drug Tryushanadi guggulu and Amruthadi guggulu was given to the study group and comparison group for a period of two months. Statistical analysis revealed no significant difference in action of Tryushanadi guggulu and Amruthadi guggulu in borderline elevation of Lipid profile.

\section{INTRODUCTION}

Non communicable diseases are the top cause of death worldwide, killing more than 36 million people in 2008. Cardiovascular diseases (CVD) are the most prevalent cause of death and disability in both developed as well as developing countries.

Disorders of lipoprotein metabolism are collectively referred to as "dyslipidemias." Dyslipidemias are generally characterized clinically by increased plasma levels of cholesterol, triglycerides, or both, variably accompanied by reduced levels of HDL cholesterol ${ }^{1}$.Dyslipidemia is an important modifiable risk factor for coronary artery disease. Research over the past 4 decades has consistently shown the burden of dyslipidemia to be very high in terms of morbidity, mortality, and medical expenses.

In Ayurveda, dyslipidemia can be corelated as a condition in which kapha, medas, rasa and agni are transformed pathologically. Treatment for Medoroga and Sthoulya can be adopted for dyslipidemia. The study drugs selected here are Tryushanadi Guggulu mentioned in Bhavaprakasha, Medorogaadhikara ${ }^{2}$ and Amrutadiguggulu mentioned in Cakradatta sthoulyachikitsa ${ }^{3}$. Study aims to clinically evaluate and compare the effect of both the drugs and to record the result scientifically for future research purposes.

\section{Dyslipidemia-Ayurvedic Perspective}

Agni is responsible for all the metabolic activities taking place in the body ${ }^{4}$.

Metabolic processes maintain the normal quantity, quality, function of the dosha and dhatu and derangement of agni can bring about improper metabolism.

The cholesterol and triglycerides formed due to improper metabolism when excess and failed to assimilate, can be compared to the ama formed due to dhatwagnimandhya.

Medo-dhatwagnimandya leads to faulty formation of sthoolabhaga and kitta.

Beejadushti itself is indicative of sahaja-agnimandya predisposing the individual to improper dhatuparinama leading to its accumulation of mala bhavas in the srothas, making the individual susceptible for development of Medoroga.

\section{MATERIALS AND METHODS}

\section{Preparation Of Study Drug}

TryushanadiGuggulu

- The formulation consists of 8 drugs.

- First Seven ingredients in fine powder form added to purified guggulu .One part each of sundi, maricha, pippali, musta, chitraka, vidanga, vacha and guggulu seven part is taken.

- Guggulu was purified using Triphala Kwatha in dolayantra ${ }^{5}$.

- Chitraka was purified in churnodaka (lime water) ${ }^{6}$.

- Guggulu is added with 2 times of water and processed on fire. When guggulu attains proper paaka rest of the ingredients in powder form were added mixed well and rolled in to gutikas each weighing $500 \mathrm{mg}$.

\section{AmrutadiGuggulu}

Consists of eight drugs:

Guduchi churna-1 part ,Elachurna-2 parts,Vidangachurna 3parts

Kutajachurna - 4 parts, Vibheetakachurna-5 parts

Hareetakichurna - 6 parts, Amalakichurna -7 parts,

Sudhaguggulu-8 parts .

- Prepared pills each of 500mg weight.

\section{CLINICALTRIAL}

Study design: Non randomised control trial.

Study setting

OPD and IPD of Department of Kayachikitsa, Govt. Ayurveda College Hospital, Thiruvananthapuram

\section{INCLUSION CRITERIA}

Patients of both sexes aged 30-70 years having Total cholesterol level between $200-239 \mathrm{mg} / \mathrm{dl}$ or Triglyceride level $150-199 \mathrm{mg} / \mathrm{dl}$ or LDLlevel $130-159 \mathrm{mg} / \mathrm{dl}$.

\section{Exclusion criteria}

- Known cases of medication for coronary artery disease, cerebrovascular accidents, any type of neoplasm, renal and hepatic disorders and hypothyroidism.

- Patients under any medication for dyslipidemia.

- Patients on prolonged medication with corticosteroids or antidepressants.

- Pregnancy and lactation.

\section{Sampling technique}

44 consecutive cases satisfying inclusion and exclusion criteria was selected for the study. Patients were categorized into two groups -study group and comparison group. Thus 22 patients will come under each group. 


\section{Procedure}

Patients with elevated lipid levels in blood investigations came to the study setting was selected in non-randomised method. The selected subjects satisfying the inclusion and exclusion criteria were subjected to detailed clinical examination and laboratory investigations. Study group was given Tryushanadiguggulu and comparative group was given Amruthadi guggulu for 60 days.

Dose Of The Drug: Each 2 gutikas 3 times daily half hour before food with luke warm water.

Outcome Variables: Changes in Total cholesterol, Triglyceride HDL, VLDL and LDL values were recorded.

\section{STATISTICAL ANALYSIS}

Pre and post comparison of quantitative variables assessed by Paired t test.

\section{RESULT}

Effectiveness of Treatment on Total Cholesterol Table 1 : Data Related to Total Cholesterol

\begin{tabular}{|c|c|c|c|c|c|c|}
\hline & \multicolumn{4}{|c|}{ Total Cholesterol } & \multirow{2}{*}{$\mathrm{p}$} \\
\cline { 2 - 6 } & Amruthadiguggulu & Tryushanadiguggulu & & \\
\cline { 2 - 5 } & Mean & $\begin{array}{c}\text { Standard } \\
\text { Deviation }\end{array}$ & Mean & $\begin{array}{c}\text { Standard } \\
\text { Deviation }\end{array}$ & & \\
\hline $\begin{array}{c}\text { Before } \\
\text { Treatment }\end{array}$ & 227.1 & 10.0 & 223.7 & 9.9 & 1.068 & 0.292 \\
\cline { 1 - 5 } $\begin{array}{c}\text { After } \\
\text { Treatment }\end{array}$ & 220.8 & 25.1 & 212.2 & 24.2 & 1.099 & 0.279 \\
\cline { 1 - 5 } $\begin{array}{c}\text { After } \\
\text { Follow up }\end{array}$ & 224.4 & 23.2 & 219.4 & 26.7 & 0.632 & 0.531 \\
\hline
\end{tabular}

The $p$ value for the change in total cholesterol is .279. $p$ value $>$ .05. The change in total cholesterol is statistically not significant in both groups.

Table 2 Between Group Comparison ForTotal Cholestrol

\begin{tabular}{|l|l|l|}
\hline $\begin{array}{l}\text { Paired Comparison } \\
\text { P values }\end{array}$ & Amruthadiguggulu & Tryushanadiguggulu \\
\hline BT vs AT & 0.200 & 0.010 \\
\hline BT vs AF & 0.600 & 0.384 \\
\hline
\end{tabular}

Between groups value for Tryushanadiguggulu after treatment is .010 . the $\mathrm{p}$ value $<.05$. On comparing before treatment and after treatment values for Tryushanadiguggulu is statistically significant for change in total cholestrol.

Effectiveness of Treatment on HDL

Table 3 Data Related To RespomseTo HDL

\begin{tabular}{|c|c|c|c|c|c|c|}
\hline \multirow{4}{*}{} & \multicolumn{5}{|c|}{ HDL } & \multicolumn{2}{|c|}{} \\
\cline { 2 - 5 } & Amruthadiguggulu & Tryushanadiguggulu & \multicolumn{2}{|c|}{} \\
\cline { 2 - 7 } & Mean & $\begin{array}{c}\text { Standard } \\
\text { Deviation }\end{array}$ & Mean & $\begin{array}{c}\text { Standard } \\
\text { Deviation }\end{array}$ & $\mathrm{t}$ & $\mathrm{P}$ \\
\hline $\begin{array}{c}\text { Before } \\
\text { Treatment }\end{array}$ & 53.9 & 12.7 & 46.9 & 8.2 & 2.067 & 0.046 \\
\hline $\begin{array}{c}\text { After } \\
\text { Treatment }\end{array}$ & 50.3 & 10.0 & 48.0 & 8.0 & 0.786 & 0.437 \\
\hline $\begin{array}{c}\text { After } \\
\text { Follow up }\end{array}$ & 53.0 & 10.4 & 47.3 & 6.3 & 2.107 & 0.042 \\
\hline
\end{tabular}

Mean HDL in the study group is $46.9+/-8.2$ before treatment, $48.0+/-8.0$ after treatment with $p$ value $>.05$ which is not significant statistically. The mean value of HDL in the comparison group before treatment is $53.9+/-12.7$ and after treatment is $50.3+/-10.0$ with $p$ value .042 .

Table 4 Between Group Comparison For HDL

\begin{tabular}{|l|l|l|}
\hline $\begin{array}{l}\text { Paired comparison } \\
\text { p values }\end{array}$ & $\begin{array}{l}\text { AMRUTHADI } \\
\text { GUGGULU }\end{array}$ & $\begin{array}{l}\text { TRYUSHANADI } \\
\text { GUGGULU }\end{array}$ \\
\hline BT vs AT & 0.013 & 0.459 \\
\hline BT vs AF & 0.606 & 0.791 \\
\hline
\end{tabular}

The paired comparison $\mathrm{p}$ values for between group
October - 2020 | PRINT ISSN No. 2250 - 1991 | DOI : 10.36106/paripex

assessment of Tryushanadiguggulu and Amruthadiguggulu shows $\mathrm{p}$ value .013 for after treatment values of changes in HDL for Amruthadiguggulu which shows a statistically significant reduction in $\mathrm{HDL}$.

\section{Effectiveness of Treatment on LDL}

Table 5 Data Related To LDL

\begin{tabular}{|c|c|c|c|c|c|c|}
\hline \multirow{1}{*}{} & \multicolumn{4}{|c|}{ LDL } & $\mathrm{t}$ & $\mathrm{p}$ \\
\cline { 2 - 6 } & $\begin{array}{c}\text { AMRUTHADI } \\
\text { GUGGULU }\end{array}$ & \multicolumn{2}{|c|}{ TRUSHANADI } & & \\
\cline { 2 - 6 } & Mean & Sd & mean & sd & & \\
\hline Before Treatment & 139.4 & 14.6 & 147.0 & 11.7 & -1.794 & 0.081 \\
\hline After Treatment & 140.1 & 23.5 & 136.1 & 25.1 & 0.517 & 0.608 \\
\hline After Follow up & 144.9 & 22.1 & 139.6 & 35.1 & 0.564 & 0.576 \\
\hline
\end{tabular}

The results are not statistically significant.

Table 6 Between Group comparison For LDL

\begin{tabular}{|l|l|l|}
\hline Paired comparison $\mathrm{p}$ values & $\begin{array}{l}\text { AMRUTHADI } \\
\text { GUGGULU }\end{array}$ & $\begin{array}{l}\text { TRYUSHANADI } \\
\text { GUGGULU }\end{array}$ \\
\hline BT vs AT & 0.863 & 0.020 \\
\hline BT vs AF & 0.248 & 0.249 \\
\hline
\end{tabular}

The changes in LDL for both study group and comparison group is not statistically significant.

\section{Effectiveness of Treatment on VLDL}

Paired comparison $p$ values of VLDL for both groups $>.05$ and between group analysis after treatment and after follow up for both groups not statistically significant.

Effectiveness of Treatment on Triglycerides

Table 7 Data Related To Triglycerides

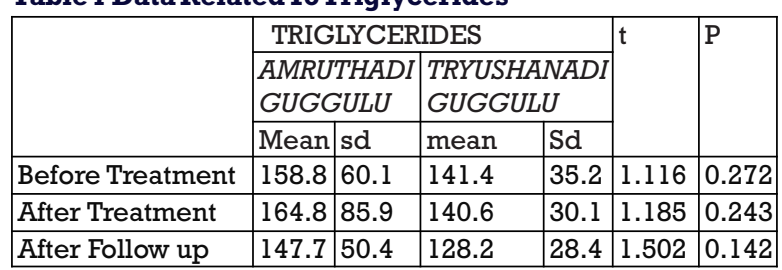

The $\mathrm{p}$ values $>.05$ and the results are not statistically significant.

\section{Table 8 Between Group Comparison For Triglycerides}

\begin{tabular}{|l|l|l|}
\hline $\begin{array}{l}\text { Paired comparison } \mathrm{p} \\
\text { values }\end{array}$ & $\begin{array}{l}\text { AMRUTHADI } \\
\text { GUGGULU }\end{array}$ & $\begin{array}{l}\text { TRYUSHANADI } \\
\text { GUGGULU }\end{array}$ \\
\hline BT vs AT & 0.655 & 0.925 \\
\hline BT vs AF & 0.292 & 0.176 \\
\hline
\end{tabular}

Paired comparison $p$ values of both group $>.05$ and the results are not statistically significant.

\section{DISCUSSION}

This study attempts to compare the effects of Tryushanadiguggulu and Amruthadiguggulu for further utilisation of therapeutic management for Dyslipidemia apart from ensuring the safety and tolerability of the drug.

- Gastritis was noted in four patients.

- Negative response for the study may be due to borderline elevations of lipid profile selected for inclusion criteria and the smaller sample sizes for the study conducted.

- Study should be conducted in dietary related, inherited and hepatic level Dyslipidemia as three separate groups with the same drug to asses any difference in the mode of action.

\section{CONCLUSION}

There is no statistically significant result obtained for the present study. Only between group comparison value for Total cholesterol of study group who were given Tryushanadi guggulu showed a positive response, but is not comparable.

\section{REFERENCES}

1. Harrisons Principles of Internal medicine; 19th edition 421/2438 
PARIPEX - INDIAN JOURNAL OF RESEARCH | Volume - 9 | Issue - 10 | October - 2020 | PRINT ISSN No. 2250 - 1991 | DOI : $10.36106 /$ paripex

2. Bhavamisra:Bhavaprakasha 39/31

3. Cakrapanidatta: Cakradatta 36/17

4. Charaka:Charaka samhitha; Ayurveda dipika Commentary by Chakrapanidatta, chikitsa sthana 15/4Varanasi: Chaukhamba Surbharati Prakashan;2011.

5. Ayurvedic Pharmacooepia of India: Ministry Of Health and Family Welfare, Govt of India,Dept of ISM \&H: Part I ; Second edition;2003,p 203.

6. Ayurvedic Pharmocoepia of India, Ministry Of Health and Family Welfare, Govt of India, Dept of ISM \&H, Controller Of Publications, Civil Lines ,Delhi, First edition, Part 1, Vol 1,p29-30. 